ISSN: 2224-0616

Int. J . Agril. Res. Innov. \& Tech. 7 (1): 22-26, December, 2017 Available online at http:// www.ijarit.webs.com

\title{
FARMERS' PERCEPTION OF ADOPTION OF POST-HARVEST TECHNOLOGIES OF SELECTED FOOD CROPS IN RIVERS STATE, NIGERIA
}

\author{
M.K. Elemasho"*, S.D.Y. Alfred'2, C.C. Aneke', A.J.C. Chugali1 ${ }^{\text {and O. Ajiboye1 }}$ \\ Received 23 July 2017, Revised 16 October 2017, Accepted 24 December 2017, Published online 31 December 2017
}

\begin{abstract}
The study was conducted to determine the perception of food crops farmers on adoption of selected post-harvest technologies in Rivers State, Nigeria. A multistage snow-ball, procedure was used to sample 135 selected food crops farmers in the State. A well, structured questionnaire was used to obtain information from the respondents using both descriptive and inferential statistical tools. The result revealed that, majority (85.9\%) of the respondents, were females while $84.4 \%$ of the respondents were married. The mean age of the respondent was 41.0 years and highly experienced in food crops production with mean of 15.9 years experience. Majority of the respondents (77\%) attended primary school. The level of food crops farmers' perception on adoption of post-harvest technologies packages was positive, majority (78.1\%) of the respondents agreed with the positive statements on adoption of post-harvest technologies, implying the possibility of high level of adoption of post-harvest technologies. The perception of the food crops farmers also had influence on adoption level of the selected post-harvest technologies packages with $(\mathrm{P}<0.05)$. The study concluded that food crops farmers had positive perception of post-harvest technologies in the study area and the study therefore, recommends that Extension should make the technologies available along with training.
\end{abstract}

Keywords: Perception, Adoption, Post-Harvest, Technologies, Food crops

${ }^{1}$ Nigerian Stored Products Research Institute, Port-Harcourt, Nigeria

${ }^{2}$ Department of Agricultural Extension and Communication Technology, Federal University of Technology, Akure, Nigeria

*Corresponding author's email: emulkat@gmail.com (M.K. Elemasho)

\section{Introduction}

Agricultural practice provides the basic needs of life in terms of food, shelter and clothing, which results in better living standard in Nigeria. This vital sector is mainly characterized with the use of simple tools and primitive ideas, which result in low productivity and low income. According to Seidu et al. (2012) for agriculture to remain the back bone of Nigerian economy, it needs to be given the needed attention, which can be achieved by implementing modern technologies in the processing, storage and marketing of food crops.

Ogunremi and Oladele (2012) also supported that, for Agriculture to be profitable new technologies must be adopted, and that, the perception of the farmers on adoption of innovation plays a vital role. Are the farmers seeing adoption of post-harvest technologies as a necessity or optional? This is because farmers' attitudes towards an innovation could determine the level of adoption of that particular technology. This agrees with Jabil and Abdu (2012) who reported that the level of adoptability of innovation by farmers depends on the attitudes of the farmers towards the agents and his information.
However, Research institutes such as Nigerian Stored Products Research Institute (NSPRI), a well organized research institute, have designed and disseminated technological innovations to farmers on post-harvest losses reduction through exhibition, community development programme and agricultural shows (Williams, 2013). Farmers remain conservative and unwilling to adopt postharvest technologies despites all the efforts. It is on this basis that this study assessed the perception of food crops farmers on post-harvest technologies of some selected food crops in Rivers State, Nigeria.

The specific objectives are to; ascertain the socioeconomic characteristics of the selected food crops farmers in Rivers State; determine the food crops farmers perception on the adoption of selected post-harvest technologies; identify the post-harvest technologies that have been adopted from the packages; and determine the level of adoption of selected post-harvest technologies by the selected food crops farmers in the study area. 


\section{Materials and Methods}

The study was carried out in Rivers State, Nigeria. The state has 23 Local Government Areas (RSMOA, 2014). It lies between latitude $4.7500^{\circ} \mathrm{N}$ and longitude $6.8333^{\circ} \mathrm{E}$, with a total land mass of about 1,940,000 ha. Large (39\%) fertile flat plain at the upland areas and water bodies covers about $60 \%$ of the rest surface areas.

The following food crops farmers (Plantain, Vegetables and Maize farmers) constituted the population for the study. A multistage snow-ball sampling technique was used to sample 135 respondents. The first stage involved, purposive selection of three local government areas Etche, Abual/Odual and Oyigbo (L.G.As) that fell on upland areas, where there is cultivable land for Agriculture.

The second stage was selection of three villages within each LGA where crops production is fully practiced, while from each village, 75 selected food crops farmers' names lists were collected through snow ball technique making a total of 675 lists collected from all the villages selected. Lastly, random sampling was used to select 15 respondents from each village in the three local government areas, making total of 135 respondents for the study.

Data were collected from the respondents using structured questionnaire. It contained relevant questions based on the objectives of the study. The dependent variable for the study was the adoption of post-harvest technologies, which was measured by adoption scores.

The independent variables were, age measured at interval level, sex measured at nominal, years of formal education measured at ordinal, household sizes measured at interval and years of farming experience was also measured at interval while perception of post-harvest technologies were asked in degrees and measured at ordinal level by using five- point Likert type scale such as strongly agreed (5), agreed (4), undecided (3), disagreed (2) and strongly disagreed (1) for positive statements and the scores were reversed for negative statements. Technologies adopted from the packages was asked in dichotomy and measured at nominal level such as adopted (1) and not adopted (2). Descriptive statistics such as frequency, percentage and mean were used to categorize respondents based on their socioeconomic characteristics. It was also used for technologies adopted from the packages.

Inferential statistics were used to establish a relationship between farmers' perception and adoption level of post-harvest technologies. Perception level was determined with the use of grand mean, the perception statement with the mean above the grand mean was categorized as positive perception and those with the mean below the grand mean was termed negative perception.

\section{Results and Discussion}

\section{Socio economic characteristics of the respondents}

Table 1 revealed that $60.6 \%$ of the respondents were young, and were within the active age group of 25-45 years. The mean age of the respondents was 41.0 years. The implication of the mean age on adoption of post-harvest technologies is that the young farmers can take risk by adopting new technologies than the older farmers.

This supports Jabil and Abdu (2012) that young farmers are willing to adopt new genes than the older ones and they are not aversive to risk.

Most of the respondents (85.9) were females, meaning that women dominated food crop production in the study area. Olayemi et al. (2012) also reported that women are more involved in agricultural activities than men in the study area. More so, $84.4 \%$ of the respondents were married. The implication of this is on social responsibility, the married people would be more responsive to innovation adoption to increase their productivity to be able to cater for the family. This corroborates Dauda et al. (2014) who indicated that married people would be responsive to innovation since they would have family responsibility. The majority (77\%) of the respondents attempted primary schools while $23 \%$ of the respondents had no formal education. This implies that the majority of the respondents were literates and this could encourage effective use of post-harvest technologies. In addition, the mean of the years of farming experience was 15.09 years, meaning that the respondents had been farming for long, they are highly experienced in the crop production and this could make farmers to make comparisons for what they have been having from their old practice. Such judgment could enhance their turning around.

This correlates with Jabil and Abdu (2012) who stated in their findings that adoption of innovation by farmers is affected by many factors such as farmers' conservative attitude towards innovation. Furthermore, it was found that the mean for the house hold sizes was six persons per family. This may imply that labor for the postharvest activities were readily supplied by the family member. 
Table 1. Distribution of respondents according to socio-economic characteristics ( $\mathrm{N}=135)$.

\begin{tabular}{|c|c|c|c|}
\hline Socio-Economic Characteristics & Frequency & Percentage & Mean \\
\hline \multicolumn{4}{|l|}{ Age(Years) } \\
\hline$<25$ & 1 & 0.7 & \multirow{5}{*}{41.0} \\
\hline $25-35$ & 47 & 34.8 & \\
\hline $36-45$ & 46 & 34.1 & \\
\hline $46-55$ & 31 & 23.0 & \\
\hline$>55$ & 10 & 7.4 & \\
\hline \multicolumn{4}{|l|}{ Sex } \\
\hline Female & 116 & 85.9 & \multirow{8}{*}{3.09} \\
\hline Male & 19 & 14.1 & \\
\hline \multicolumn{4}{|l|}{ Years of formal Education } \\
\hline 6years & 42 & 31.2 & \\
\hline 9years & 8 & 5.9 & \\
\hline 12 years & 40 & 29.6 & \\
\hline $15 y e a r s$ & 8 & 5.9 & \\
\hline 17years & 6 & 4.4 & \\
\hline Non formal & 31 & 23 & \\
\hline \multicolumn{4}{|l|}{ House-Hold Size } \\
\hline $1-4$ & 45 & 33.3 & \multirow{9}{*}{6} \\
\hline $5-9$ & 74 & 54.8 & \\
\hline $10-14$ & 13 & 9.6 & \\
\hline 15-19 & 3 & 2.3 & \\
\hline \multicolumn{3}{|l|}{ Marital Status } & \\
\hline Single & 13 & 9.6 & \\
\hline Married & 114 & 84.4 & \\
\hline Widowed & 7 & 5.3 & \\
\hline Divorced & 1 & 0.7 & \\
\hline \multicolumn{4}{|l|}{ Years of Farming Experience } \\
\hline $1-10$ & 45 & 34.2 & \\
\hline $11-20$ & 63 & 46.6 & 15.9 \\
\hline $21-30$ & 20 & 14.8 & \\
\hline $31-40$ & 6 & 4.4 & \\
\hline
\end{tabular}

Source: Field Survey, 2015

\section{Perception of the post-harvest technologies adoption by the food crops farmers}

Table 2 showed the perception of the respondents to both positive and negative statements about adoption of post-harvest technologies. All the positive statements have the mean ranging from 4.3 to 4.7 indicating decision to adopt postharvest technologies since they all agreed with the positive statements on post-harvest technologies adoption and rejected negative statement that discourage adoption of post-harvest technologies.

The mean for each of the negative statement was 1.4 indicating strongly disagreed with negative opinions on adoption of post-harvest technologies. The grand mean is 3.8 indicating agreed. Meaning, the respondents are willing to adopt post-harvest technologies in the packages because of their positives perception

\section{Level of farmers' perception on adoption of post-harvest technologies}

Table 3 revealed that $78.1 \%$ of the respondents had positive perception for adoption of selected post-harvest technologies of food crops while $21.9 \%$ of the respondents had negative perception for adoption of selected post-harvest technologies of food crops. This implies that the future hope of adopting the selected post-harvest technologies is very high in the study area.

\section{Post-harvest technologies adopted from the packages by the farmers}

Table 4 shows that $100 \%$ of the respondents claimed that all the post-harvest technologies in the packages were not adopted, meaning that extension service was poor and not successful in the study area. This corroborates with Ochuk (2013) who reported that adoption of innovation remained the major yard stick for determining the success of Agricultural extension services on the intended beneficiaries.

\section{Level of adoption of selected post-harvest technologies}

Table 5 revealed that $100 \%$ of the respondents poorly adopted the selected post-harvest technologies in the study area. Therefore, most of the food crops (plantain, vegetable and maize) produced could be lost at post harvest stages in the study area because of non-adoption of postharvest technologies and this could lead to lower out-put of food crops and reduction in income and poor standard of living of the food crops farmers. This agrees with Olayemi et al. (2012) and Owolade (2011) who reported that, most of agricultural produce are lost during post-harvest handling and that up to $50-70 \%$ losses are estimated between production area and consumption point because of inadequate postharvest handling and non adoption of postharvest technologies. Olayemi et al. (2012) also explained further that post-harvest losses will lead to reduction in farmers' income, food 
insecurity, poor nutritional value and lack of Table 6 showed that there is a significant input for the next production

Relationship between farmers' perception and their level of adoption of post-harvest technologies

relationship between farmers' perception and adoption of post-harvest technologies in the study area, as the $\mathrm{p}$ value is less than 0.05 . This shows that positive perception could lead to high level of adoption of post-harvest technologies.

Table 2. Distribution of the respondents according to their perception of post-harvest technologies.

\begin{tabular}{|c|c|c|c|c|c|c|c|}
\hline Perception Statements & $\mathrm{SA}$ & A & UD & $\mathrm{D}$ & SD & $\begin{array}{l}\text { Mean } \\
\text { Score }\end{array}$ & Decision \\
\hline $\begin{array}{l}\text { i. Adoption of post-harvest technologies is } \\
\text { essential }\end{array}$ & $84(62.2)$ & $46(34.0)$ & $2(1.5)$ & $2(1.5)$ & $1(0.7)$ & 4.6 & Accept \\
\hline $\begin{array}{l}\text { ii Post-harvest technologies adoption is } \\
\text { necessary }\end{array}$ & $84(62.2)$ & $46(34.0)$ & $2(1.5)$ & $2(1.5)$ & $1(0,7)$ & 4.6 & Accept \\
\hline $\begin{array}{l}\text { iii. Modern post-harvest technologies } \\
\text { adoption are better than using local tools }\end{array}$ & 78(57.8) & $47(34.8)$ & $8(5.9)$ & $1(0.7)$ & $1(0.7)$ & 4.5 & Accept \\
\hline $\begin{array}{l}\text { iv Post-harvest technology adoption } \\
\text { reduces post-harvest activities stresses in } \\
\text { crop productions }\end{array}$ & 86(63.7) & $46(34.1)$ & $1(0.7)$ & $1(0.7)$ & $1(0.7)$ & 4.6 & Accept \\
\hline $\begin{array}{l}\text { v. Post-harvest technologies should be } \\
\text { adopted regardless of costs }\end{array}$ & $58(42.9)$ & $63(46.7)$ & $11(8.1)$ & $2(1.5)$ & $1(0.7)$ & 4.3 & Accept \\
\hline $\begin{array}{l}\text { vi Adoption of post-harvest technologies } \\
\text { cannot reduce post-harvest losses of crops }\end{array}$ & $1(0.7)$ & $1(0.7)$ & $3(2.2)$ & 43(31.9) & $87(64.4)$ & 1.4 & Reject \\
\hline $\begin{array}{l}\text { vii Co-farmers should be discouraged from } \\
\text { adopting post-harvest technologies }\end{array}$ & $1(0.7)$ & $1(0.7)$ & $4(3.0)$ & 42(31.1) & $82(60.7)$ & 1.4 & Reject \\
\hline $\begin{array}{l}\text { viii Post-harvest technologies adoption can } \\
\text { raise farmers to maximum standard of }\end{array}$ & $82(60.7)$ & $50(37.0)$ & $1(0.7)$ & $1(0.7)$ & $1(0.7)$ & 4.6 & Accept \\
\hline $\begin{array}{l}\text { ix Post-harvest technologies should be } \\
\text { adopted on a permanent basis }\end{array}$ & 110(81.5 & $20(14.8)$ & $2(1.5)$ & $2(1.5)$ & $1(0.7)$ & 4.7 & Accept \\
\hline
\end{tabular}

Adoption $(\mathrm{N}=135)$

Source: Field Survey, 2015 Grand Mean: 3.8

Legends for positive statements: SA=Strongly Agreed 5, A=Agreed 4, UD=Undecided 3, D=Disagreed 2, SD=Strongly Disagreed 1

Legends for negative statements: $\mathrm{SA}=$ Strongly Agreed 1, A=Agreed 2, UD=Undecided 3, D= Disagreed 4, SD=Strongly Disagreed 5

Table 3. Distribution of the respondents according to the level of perception on adoption of postharvest technologies.

\begin{tabular}{lcc}
\hline Perception Level & Frequency & Percentage (\%) \\
\hline Positive( ) & 945 & 78.1 \\
Negative ( ) & 265 & 21.9 \\
\hline Total & 1210 & 100 \\
\hline
\end{tabular}

Source: Field Survey, 2015

Table 4. Distribution of the respondents according to the technologies adopted.

\begin{tabular}{lll}
\hline Post-harvest technologies & $\mathrm{A}(\%)$ & $\mathrm{NA}$ \\
& $\mathrm{F}(\%)$ \\
\hline Plastic crates: Plantain & $0(0)$ & $135(100)$ \\
Plantain slicers: Plantain & $0(0)$ & $135(100)$ \\
Multipurpose dryer: Plantains, Vegetable and maize & $0(0)$ & $135(100)$ \\
Transparent polythene nylon: Plantain and Vegetable & $0(0)$ & $136(100)$ \\
Sealing machine: Plantain and Vegetable & $0(0)$ & $135(100)$ \\
NSPRI vegetable basket: Vegetable & $0(0)$ & $135(100)$ \\
Vegetable shed: Vegetable & $0(0)$ & $135(100)$ \\
Metal cribs: Maize & $0(0)$ & $135(100)$ \\
Inert atmosphere silo: Maize & $0(0)$ & $135(100)$ \\
Improved ware-house: Maize & $0(0)$ & $135(100)$ \\
\hline Total & $0(0)$ & $135(100)$ \\
\hline Sol
\end{tabular}

Source: Field Survey, 2015 
Table 5. Distribution of the respondents according to the level of adoption of post-harvest technologies $(\mathrm{N}=135)$.

\begin{tabular}{lcc}
\hline Level of adoption & Frequency & Percentage (\%) \\
\hline Poor Adoption & 135 & 100.0 \\
Fair Adoption & - & - \\
Good Adoption & - & - \\
\hline Total & 135 & 100 \\
\hline
\end{tabular}

Source: Field Survey, 2015

Table 6. Relationship between farmer's perception and their level of adoption of post-harvest technologies.

\begin{tabular}{lllcc}
\hline Relationship & $x^{2}$ & Df & P-value & Decision \\
\hline $\begin{array}{l}\text { Perceptions Scores vs } \\
\text { Level of Adoption of }\end{array}$ & & & & \\
$\begin{array}{l}\text { Post-harvest } \\
\text { Technologies }\end{array}$ & 131.030 & 1 & 0.000 & $\mathrm{~S}$ \\
\hline
\end{tabular}

*Significant at $0.05, \mathrm{~S}=$ Significant, NS = Not Significant

Decision: P-value is significant when less than 0.05

\section{Conclusion}

The study concludes that the perception level of food crops farmers on post-harvest technologies was positive and the future hope of adopting the selected post-harvest technologies in the study area is very high.

\section{Recommendation}

Research institutes, ADPs and NGOs should work in collaborations to develop awareness programs and Extension should make the technologies available along with training.

\section{References}

Dauda, A.W., Oladoja, M.A. and Aderinto, A. 2014. Effects of fadama lll projects on empowerment scheme on cow-pea production in Iseyin Local Government area of Oyo State. Annals Child Youth Stud. 5(1): 78.

Jabil, I.Y and Abdu, U.D. 2012. Socio-economic characteristics of farmers and the factors that hampers their Adoption of Agricultural Technologies in Northern Central Zones of Plateau State, Nigeria. Int. J. Agril. Econ. Ext. 4 (1): 5.
Ochuk, O. 2013. A frame work for measuring adoption of innovations: Improved cassava varieties in Delta State Nigeria. Ext. Farm. Syst. J. 9 (1): 171-177.

Ogunremi, J.B. and Oladele, O.I. 2012. Adoption of aquaculture technology by fish farmers in Lagos State Nigeria. Life Sci. J. 9 (2): 329333.

Olayemi, F.F., Adegbola, J.A., Bamishaiye, E.I. and Awagu, E.F. 2012. Assessment of Postharvest losses of some selected crops in eight local government areas of Rivers State, Nigeria. Asian J. Rural Dev. 2 (1): 13-23.

Owolade, S.O. 2011. Promotion of food Security through reduction in post-harvest losses of horticulture crops in Nigeria. Hort. 1 (9): 14 16.

RSMOA. 2014. Agricultural investment opportunities in Rivers State, Nigeria. Rivers State Ministry of Agriculture. p.1.

Seidu, J.M., Issah, A., George, E. and Mahama, A.A. 2012. Processing plantain into high quality flour using solar dryers. Int. J. Agril. Econ. Ext. 4: 11.

Williams, J.O. 2013. Welcome to Nigerian Stored Products Research Institute (NSPRI) Federal Ministry of Agriculture and Rural Development. Published by, Adewumi Press Ilorin. pp. 5-45. 